\title{
AN ANALYSIS OF THE RELATIONSHIP BETWEEN FOREIGN DIRECT INVESTMENT AND SUSTAINABLE DEVELOPMENT*
}

\section{Türkiye'de Doğrudan Yabancı Sermaye Yatırımları ve Sürdürülebilir Kalkınma İlişskisinin Analizi}

\section{Canan ŞENTÜRK ${ }^{* *}$ \& Şerife KUYUN ${ }^{* * *}$}

\begin{abstract}
The development and welfare efforts of countries are transformed over time and creates sustainable development with an approach that considers environmental

Keywords:

Foreign Direct

Investment,

Sustainable

Development,

International

Economics,

Economic Growth,

Causality Analyses.

\section{JEL Codes:}

F0, F63, Q01, O47, $\mathrm{C} 40$ factors. If the processing of raw materials is based solely on economic benefits, it will hinder environmental and social development in the long run. Thus, the importance of sustainable development is emphasized once again with the circular economy structure. On the other hand, foreign direct investment (FDI) comes to the fore as sustainable development strategy, especially in developing economies. In this context, it is aimed to reveal whether there is a relationship between FDI and sustainable development in Turkey between 1990-2018. Unit root test, co-integration and VECM based causality analyses are included in the estimation of the relationships between these variables by using the Eviews 10 . The significance of causality relationship is also questioned with variance decomposition and impulse-response analysis. According to the findings, there is a cointegration relationship between the variables and they act together in the long run. In addition, there is one-way relationship from FDI to per capita GDP and per capita energy consumption; bidirectional causality between per capita GDP and per capita energy consumption; one-way relationship from FDI to sustainable development index.
\end{abstract}

\section{Anahtar Kelimeler: Doğrudan Yabanc1 Sermaye Yatırımları, Sürdürülebilir \\ Kalkınma, \\ Uluslararası \\ Ekonomi, \\ Ekonomik Büyüme, Nedensellik Analizi. \\ JEL Kodları: F0, F63, Q01, O47, $\mathrm{C} 40$}

\section{$\ddot{O} \mathbf{z}$}

Ülkelerin kalkınma ve refah arayışları zaman içerisinde dönüşüme uğrayarak süründürülebilir gelecek ekseninde sürdürülebilir kalkınmayı doğurmaktadır. Ham maddenin işlenerek ürün haline getirilmesi sürecinin, sadece ekonomik yararlara dayalı olmasının uzun dönemde çevresel ve sosyal gelişmeye engel olacağ1 düşünüldüğünde, döngüsel ekonomi kurgusuyla sürdürülebilir kalkınmanın önemi bir kez daha vurgulanmaktadır. Özellikle gelişmekte olan ekonomilerde sürdürülebilir kalkınma stratejisi olarak doğrudan yabancı sermaye yatırımları (DYSY) gündeme gelmektedir. Bu bağlamda çalışmada Türkiye'de 1990-2018 yılları arasında doğrudan yabancı sermaye yatırımları ile sürdürülebilir kalkınma arasında ilișki olup olmadığının ortaya konulması amaçlanmaktadır. Bu çalışmada değişkenler arasındaki ilişkilerin tahmininde, birim kök testi, eş-bütünleşme ve VECM temelli nedensellik analizlerine yer verilmektedir. Varyans ayrıştırması ve etki-tepki analizleriyle de nedensellik ilişkisinin anlamlılığı sorgulanmaktadır. Bulgulara göre, değişkenler arasında eş-bütünleşme ilişkisi bulunmakta ve uzun dönemde birlikte hareket etmektedirler. Ayrıca, DYSY'den, kişi başı GSYİH ve kişi başı enerji tüketimine doğru tek yönlü; kişi başı GSYİH ile kişi başı enerji tüketimi arasında çift yönlü; DYSY'den sürdürülebilir kalkınma endeksine doğru ise, tek yönlü nedensellik ilişkisinin varlığı sonuçlarına ulaşılmaktadır.

\footnotetext{
* This is the revised and edited version of the paper presented at the 5th International Conference on Economics Research and Financial Markets Congress (IERFM).

** Assist. Prof. Dr., Süleyman Demirel University, Faculty of Economics and Administrative Sciences, Department of Economics, canansenturk@sdu.edu.tr, ORCID: 0000-0001-7714-844X

*** Graduate Student, Süleyman Demirel University, Graduate School of Social Sciences, kuyun004@hotmail.com, ORCID: 0000-0002-9931-4995
}

Makale Geliş Tarihi (Received Date): 12.11.2021 Makale Kabul Tarihi (Accepted Date): 26.12.2021 


\section{Introduction}

The United Nations has set 17 sustainable development goals for the economies that it aims to achieve by 2030 . These are as follows that end poverty, protect the environment, provide equitable and peace-oriented societies that provide well-being for all, etc (United Nations [UN], 2015). Considering the economic dimension of sustainable development, it is seen that it aims to leave the same welfare level to future generations by increasing the welfare of the countries, as well as ensuring its sustainability. At this point, ensuring the continuity of income and consumption is defined as ensuring economic sustainability. At the same time, its environmental and social dimensions also draw the limits of economic growth. In the framework of sustainable development, it has been observed that foreign direct investment has positive and negative effects on the basis of social, environmental and economic factors. The availability of the 17 SDG creates significant investment needs, which can present several challenges for the international community. While the public sector plays an important role in mobilizing capital to achieve this goals, FDI and private sector investments are a major source of external financing, especially developing countries (United Nations Trade and Development Organization [UNCTAD], 2014).

In the global world today, foreign direct investment is a consistent necessity between national and international perspectives and plays an important role in sustainability. For this reason, high foreign direct investment points to growth, productivity, competitiveness and sustainable development. Sustainable industrial development is a priority target, especially in countries that adopt an FDI-oriented integration strategy. In this strategy, which is tried to be coordinated with the increase in internal production capacity, the environmental performance of the industry and employment, the main target is sustainability (Gallagher, 2005, p. 24). It is also thought that the country that makes foreign direct investment will close the investment deficits caused by the savings deficiencies of the host country. It has been observed that the effects of innovation, renewableness, employment, production increase and economic growth in the sectors, in which they invest, have a significant place in the realization of the objectives within the economic dimension of sustainable development. This is also supported by Neo-classical theory. According to the neo-classical theory, FDI will benefit economic development in the host country through the inflow of capital, growth in the labour force, and enhancement of technological progress (Aust, Morais and Pinto, 2020, p. 2). In this context, the economic effects of FDI on sustainable development can be divided into macro and micro effects. While macroeconomic effects focus on economic growth and investments, micro effects focus on firm advantages and disadvantages. Macroeconomic impacts can be expressed as elements such as increasing economic growth, investment and employment; helping to overcome the capital shortage, contributing to closing current account deficits and negatively affecting the balance of payments by causing an increase in imports. Microeconomic effects of FDIs on sustainable development such as increasing labour productivity, enabling the increase of management skills, export and import level, providing new products and equipment. And it may also cause an increase in the production of national firms or a decrease in the production of national firms (Chudnovsky and Lopez, 2008).

In this study, which examines the relationship between sustainable development and foreign direct investment in Turkey, time series of the years 1990-2018 are used. When the studies in the literature are examined, it is seen that variables such as economic growth, carbon emission rate, energy consumption, trade openness, and R\&D expenditures are used to represent sustainable development. All these and similar variables are the results of researches on how to 
measure and evaluate the progress of sustainable development in terms of countries, which has come to the fore since the 1990s. Along with the sustainable development indicators created by the UN, alternative international organizations such as the Economic Cooperation Organization, the World Bank and the European Union have studies in this field. From this point of view, GDP per capita and energy consumption per capita are chosen in this study, due to its decisive role in macroeconomic performance. On the other hand, Sustainable Development Index (SDI) is chosen as the focus variable, because it contains multiple variables and two modelling has been done.

\section{Literature Review}

The effects of foreign direct investments on sustainable development cause long and interesting discussions both in theory and in practice. The differentiation of the indicator values representing sustainable development also adds dimension to these discussions. The studies in Table 1 also focus on different indicators representing sustainable development and are presented in a holistic framework regarding the relationship between foreign direct investment and sustainable development.

It is seen that the effects of FDI on economic, social and environmental factors, which are the basic dimensions of sustainable development. While some of the studies in the literature revealed that FDI have positive effects on sustainable development, some of them state that these effects are very limited or not at a level to establish causality. 
Ekonomi, Politika \& Finans Araştırmaları Dergisi, 2021, 6(Özel Sayı): 33-53

Journal of Research in Economics, Politics \& Finance, 2021, 6(Special Issue): 33-53

Araştırma Makalesi, DOI: 10.30784/epfad.1022499

Table 1. Literature Review of the Relationship between Foreign Direct Investments and Sustainable Development

\begin{tabular}{|c|c|c|c|c|c|}
\hline Study & $\begin{array}{c}\text { Time } \\
\text { Period }\end{array}$ & Country & $\begin{array}{l}\text { Representative } \\
\text { Indicators }\end{array}$ & Method & Conclusion \\
\hline Gallagher (2005) & 1994-2002 & Mexico & $\begin{array}{l}\text { FDI, Employment, } \\
\text { Export, Environmental } \\
\text { Performance }\end{array}$ & $\begin{array}{l}\text { Data } \\
\text { Comparison }\end{array}$ & $\begin{array}{l}\text { Despite the increase in FDI inflows and exports in the } \\
\text { manufacturing sector, it has little contribution to support } \\
\text { internal productivity capacity with the FDI-led } \\
\text { integration strategy implemented in Mexico. }\end{array}$ \\
\hline $\begin{array}{l}\text { Pirtea and Milos } \\
(2009)\end{array}$ & $2001-2006$ & Romania & FDI, GDP & $\begin{array}{l}\text { Regression } \\
\text { Analysis }\end{array}$ & $\begin{array}{l}\text { No significant relationship is found between foreign } \\
\text { direct investment and economic growth, which is used } \\
\text { as an indicator of sustainable development. }\end{array}$ \\
\hline $\begin{array}{l}\text { Georgantopoulos and } \\
\text { Tsamis (2011) }\end{array}$ & $1970-2009$ & Greece & FDI, GDP & $\begin{array}{l}\text { Cointegration } \\
\text { and Granger } \\
\text { Causality Tests }\end{array}$ & There is one-way causality running from GDP to FDI. \\
\hline $\begin{array}{l}\text { Pao and Tsai } \\
(2011)\end{array}$ & $\begin{array}{l}\text { Rusya; } \\
\text { 1992-2007 } \\
\text { Diğerleri; } \\
\text { 1980-2007 }\end{array}$ & $\begin{array}{l}\text { Brasil, } \\
\text { Russia, } \\
\text { India } \\
\text { China }\end{array}$ & $\begin{array}{l}\mathrm{FDI}, \mathrm{CO}_{2} \text { Emissions, } \\
\text { Energy Consumption, } \\
\text { GDP }\end{array}$ & $\begin{array}{l}\text { Granger } \\
\text { Causality Tests }\end{array}$ & $\begin{array}{l}\text { One-way causality running from energy consumption to } \\
\text { emissions and from GDP to FDI; there is two-way } \\
\text { causality between emissions and FDI, emissions and } \\
\text { GDP, energy consumption and GDP. }\end{array}$ \\
\hline $\begin{array}{l}\text { Feridun and Sissoko } \\
\text { (2011) }\end{array}$ & $1976-2002$ & Singapur & FDI, GDP & $\begin{array}{l}\text { VAR and } \\
\text { Granger } \\
\text { Causality Tests }\end{array}$ & $\begin{array}{l}\text { There is one-way causality from FDI to economic } \\
\text { growth. }\end{array}$ \\
\hline $\begin{array}{l}\text { Šimelytė and } \\
\text { Antanavičienè (2013) }\end{array}$ & $\begin{array}{l}1970-1979 \\
1980-1989 \\
1990-1999 \\
2000-2007 \\
2000-2012 \\
2008-2012 \\
\end{array}$ & Ireland & $\begin{array}{l}\text { FDI, Productivity, } \\
\text { Population, GDP, Trade, } \\
\text { Labor, Energy, } \\
\text { Migration, Green Gas, } \\
\text { Electricity }\end{array}$ & $\begin{array}{l}\text { Regression } \\
\text { Analysis }\end{array}$ & $\begin{array}{l}\text { There is a relationship between FDI indicators and } \\
\text { sustainable growth in different periods of the economic } \\
\text { cycle. }\end{array}$ \\
\hline Antanavičienè (2014) & 2004-2012 & $\begin{array}{l}\text { LithuaniaLatvia } \\
\text { Estonia }\end{array}$ & FDI, GDP & $\begin{array}{l}\text { Data } \\
\text { Comparison }\end{array}$ & FDI may not deliver secure sustainable development. \\
\hline $\begin{array}{l}\text { Omri, Nguyen and } \\
\text { Rault (2014) }\end{array}$ & $1990-2011$ & 54 Countries & $\begin{array}{l}\text { FDI, } \mathrm{CO}_{2} \text { Emissions, } \\
\text { GDP }\end{array}$ & $\begin{array}{l}\text { Dynamic Panel } \\
\text { Data Analysis }\end{array}$ & $\begin{array}{l}\text { There is two-way causality between } \mathrm{CO}_{2} \text { emissions and } \\
\text { FDI and between FDI and GDP. }\end{array}$ \\
\hline $\begin{array}{l}\text { Kivyiro and Arminen } \\
(2014)\end{array}$ & $1971-2009$ & $\begin{array}{l}\text { Sub-Saharan } \\
\text { Africa }\end{array}$ & $\begin{array}{l}\text { FDI, } \mathrm{CO}_{2} \text { Emissions, } \\
\text { Energy Consumption, } \\
\text { Economic Development }\end{array}$ & $\begin{array}{l}\text { Cointegration } \\
\text { and Granger } \\
\text { Causality Tests }\end{array}$ & $\begin{array}{l}\text { GDP, energy consumption and FDI cause } \mathrm{CO}_{2} \\
\text { emissions. }\end{array}$ \\
\hline
\end{tabular}




\section{Table 1. Continue}

\begin{tabular}{|c|c|c|c|c|c|}
\hline Kardos (2014) & $2001-2010$ & $\begin{array}{c}\text { Sweden, } \\
\text { Slovakia, } \\
\text { Poland, France, } \\
\text { Spain and } \\
\text { Greece }\end{array}$ & $\begin{array}{l}\text { FDI, Sustainable Society } \\
\text { Index }\end{array}$ & $\begin{array}{l}\text { Data } \\
\text { Comparison }\end{array}$ & $\begin{array}{l}\text { Emphasizing the importance and relevance of green FDI } \\
\text { in EU countries, it is pointed out that it has a very } \\
\text { positive potential in terms of sustainable development. }\end{array}$ \\
\hline $\begin{array}{l}\text { Ren, Yuan, Ma and } \\
\text { Chen (2014) }\end{array}$ & $2000-2010$ & China & $\begin{array}{l}\text { FDI, } \mathrm{CO}_{2} \text { emissions, } \\
\text { Trade Opening, Exports, } \\
\text { Imports and Income Per } \\
\text { Capita }\end{array}$ & $\begin{array}{l}\text { Regression } \\
\text { Analysis }\end{array}$ & High FDI inflows increase $\mathrm{CO}_{2}$ emissions. \\
\hline $\begin{array}{l}\text { Voica, Panait and } \\
\text { Haralambie (2015) }\end{array}$ & $2000-2012$ & $\begin{array}{l}\text { EU } \\
\text { (28) Countries }\end{array}$ & $\begin{array}{l}\text { Social; GNP, FDI, Life } \\
\text { Expectancy at Birth, } \\
\text { Poverty and } \\
\text { Employment Rate of the } \\
\text { Elderly } \\
\text { Environmental; FDI, } \\
\text { Greenhouse Gas } \\
\text { Emissions, Renewable } \\
\text { Energy Consumption, } \\
\text { Renewable Resources } \\
\text { and Tax } \\
\text { Economic; FDI, GDP, } \\
\text { Primary Energy } \\
\text { Consumption }\end{array}$ & $\begin{array}{l}\text { Panel } \\
\text { Regression } \\
\text { Analysis }\end{array}$ & $\begin{array}{l}\text { The most important impact of FDI is on environmental } \\
\text { impact and then on social and economic indicators. }\end{array}$ \\
\hline $\begin{array}{l}\text { Davidson and Sahli } \\
(2015)\end{array}$ & $2007-2008$ & Gambia & $\begin{array}{l}\text { FDI, Tourism Sector } \\
\text { Data }\end{array}$ & $\begin{array}{l}\text { Data } \\
\text { Comparison }\end{array}$ & $\begin{array}{l}\text { FDI is concentrated in larger and luxury hotels. It is } \\
\text { emphasized that FDI is a complex tool for tourism and } \\
\text { poverty reduction. The study shows that different forms } \\
\text { of ownership in tourism businesses have advantages and } \\
\text { disadvantages, but they create the potential to be } \\
\text { complementary in terms of sustainable development. }\end{array}$ \\
\hline Güney (2015) & $1990-2012$ & OECD Countries & $\begin{array}{l}\text { FDI, Adjusted Net } \\
\text { Savings }\end{array}$ & $\begin{array}{l}\text { Panel Data } \\
\text { Analysis }\end{array}$ & $\begin{array}{l}\text { FDI does not have any significant impact on sustainable } \\
\text { development. }\end{array}$ \\
\hline $\begin{array}{l}\text { Cho and Ramirez } \\
\text { (2016) }\end{array}$ & $1990-2013$ & $\begin{array}{l}\text { South East Asian } \\
\text { Countries }\end{array}$ & $\begin{array}{l}\text { FDI and Income } \\
\text { Inequality }\end{array}$ & $\begin{array}{l}\text { Panel } \\
\text { Cointegration } \\
\text { Analysis }\end{array}$ & $\begin{array}{l}\text { FDI inflows tend to increase income inequality in the } \\
\text { short run. }\end{array}$ \\
\hline
\end{tabular}




\section{Table 1. Continue}

\begin{tabular}{|c|c|c|c|c|c|}
\hline $\begin{array}{l}\text { Abdouli and } \\
\text { Hammami (2017) }\end{array}$ & 1990-2012 & $\begin{array}{l}17 \text { MENA } \\
\text { Countries }\end{array}$ & $\begin{array}{l}\text { FDI, GDP, } \mathrm{CO}_{2} \\
\text { Emissions, Capital } \\
\text { Stock, Trade Openness, } \\
\text { Financial Development, } \\
\text { Energy Consumption } \\
\text { and }\end{array}$ & $\begin{array}{l}\text { Panel } \\
\text { Regression } \\
\text { Analysis }\end{array}$ & $\begin{array}{l}\text { There is one-way causality from FDI to GDP; and two- } \\
\text { way causality between FDI and } \mathrm{CO}_{2} \text { emission. }\end{array}$ \\
\hline $\begin{array}{l}\text { Ridzuan, İsmail and } \\
\text { Hamat (2017) }\end{array}$ & $1970-2013$ & Singapour & $\begin{array}{l}\text { FDI, SDI, } \\
\text { Environmental Quality, } \\
\text { Trade Openness and } \\
\text { Financial Development }\end{array}$ & ARDL & $\begin{array}{l}\text { FDI has a positive effect on economic growth and } \\
\text { environmental quality. High FDI inflows have negative } \\
\text { effects on income distribution. }\end{array}$ \\
\hline Simionescu (2017) & $2005-2014$ & Romania & FDI, GDP & VAR & FDI causes economic growth. \\
\hline $\begin{array}{l}\text { Ridzuan, İsmail and } \\
\text { Hamat (2018) }\end{array}$ & $1970-2013$ & Malezia & $\begin{array}{l}\text { FDI, Trade Openness, } \\
\text { GDP, Income } \\
\text { Distribution and } \\
\text { Environmental Quality }\end{array}$ & ARDL & $\begin{array}{l}\text { FDI inflows lead to higher growth, better income } \\
\text { distribution and lower pollution. }\end{array}$ \\
\hline Park (2018) & $1991-2015$ & China & $\begin{array}{l}\text { FDI, Human Capital, } \\
\text { R\&D and GDP }\end{array}$ & $\begin{array}{l}\text { Data Mining } \\
\text { and Semantic } \\
\text { Network } \\
\text { Analysis (SNA) }\end{array}$ & $\begin{array}{l}\text { FDI-Human Capital and R\&D-Human Capital have } \\
\text { positive effects on GDP in the short and long run. FDI- } \\
\text { Human Capital has strong effects on itself in the } \\
\text { medium and long term. }\end{array}$ \\
\hline Adejumo (2019) & 1970-2014 & Nigeria & $\begin{array}{l}\text { FDI, Market, } \\
\text { Manufacturing Exports, } \\
\text { Trade Liberalization and } \\
\text { Real Exchange Rate }\end{array}$ & ARDL & $\begin{array}{l}\text { In the industrial development indicator of product } \\
\text { exports, FDI in the manufacturing sector affects } \\
\text { negatively in the short run. } \\
\text { There are positive spillovers of FDI inflows in the long } \\
\text { run. }\end{array}$ \\
\hline Aust et al. (2020) & 2014-2017 & $\begin{array}{l}44 \text { African } \\
\text { Countries }\end{array}$ & $\begin{array}{l}\text { FDI, Market, } \\
\text { Manufacturing, Export, } \\
\text { Trade Liberalization and } \\
\text { Real Exchange Rate } \\
\text { Sustainable } \\
\text { Development Goals } \\
\text { Indices }\end{array}$ & $\begin{array}{l}\text { Regression } \\
\text { Analysis }\end{array}$ & $\begin{array}{l}\text { FDI has a positive impact on areas such as basic } \\
\text { infrastructure, clean water, sanitation and renewable } \\
\text { energy. However, the relationship to climate action } \\
\text { improvement is negative. }\end{array}$ \\
\hline $\begin{array}{l}\text { Rana and Sharma } \\
(2020)\end{array}$ & $1980-2014$ & India & $\begin{array}{l}\text { FDI, GDP, } \mathrm{CO}_{2} \\
\text { Emissions, Energy } \\
\text { Consumption and } \\
\text { Natural Environment }\end{array}$ & $\begin{array}{l}\text { Dynamic Toda- } \\
\text { Yamamoto }\end{array}$ & $\begin{array}{l}\text { FDI causes } \mathrm{CO}_{2} \text { emissions, energy consumption and } \\
\text { trade deficit. }\end{array}$ \\
\hline
\end{tabular}




\section{Table 1. Continue}

\begin{tabular}{|c|c|c|c|c|c|}
\hline $\begin{array}{l}\text { Ayamba, Haibo, } \\
\text { Abdul-Rahaman, } \\
\text { Serwaa and Osei- } \\
\text { Agyemang (2020) }\end{array}$ & $1996-2016$ & China & $\begin{array}{l}\text { FDI, Sulphur dioxide, } \\
\text { Smoke, Dust, GDP, } \\
\text { Industrial Solid Waste } \\
\text { and R\&D }\end{array}$ & $\begin{array}{l}\text { Regression } \\
\text { Analysis }\end{array}$ & $\begin{array}{l}\text { The impact of FDI on environmental quality is low in } \\
\text { the long run. However, pollution variables have an } \\
\text { impact on FDI inflows. }\end{array}$ \\
\hline $\begin{array}{l}\text { Mukhtarov, Aliyev, } \\
\text { Mikayilov, İsmayilov } \\
\text { and Rzayev (2020) }\end{array}$ & $1996-2013$ & Azerbaijan & $\begin{array}{l}\mathrm{FDI}, \mathrm{CO}_{2}, \text { Emissions, } \\
\text { Income Elasticity }\end{array}$ & $\begin{array}{l}\text { Time Series } \\
\text { Analysis } \\
\text { (STSM) }\end{array}$ & $\begin{array}{l}\text { There is a positive effect of FDI on } \mathrm{CO}_{2} \text { emissions } \\
\text { before 2006; a negative effect after } 2006 \text {. }\end{array}$ \\
\hline $\begin{array}{l}\text { Odugbesan, Ike, } \\
\text { Olowu and Adeleye } \\
(2020)\end{array}$ & 2004-2018 & $\begin{array}{c}33 \text { Sub-Saharan } \\
\text { African } \\
\text { Countries }\end{array}$ & $\begin{array}{l}\text { FDI, Sustainable } \\
\text { Development, Financial } \\
\text { Inclusion, Financial } \\
\text { Development, Resource } \\
\text { Leases }\end{array}$ & $\begin{array}{l}\text { Panel } \\
\text { Cointegration } \\
\text { Analysis }\end{array}$ & $\begin{array}{l}\text { There is financial participation and FDI; two-way } \\
\text { causality between financial development and FDI; one- } \\
\text { way causality from FDI to sustainable development and } \\
\text { resource rents. }\end{array}$ \\
\hline Karimov (2020) & $1970-2014$ & Turkey & $\begin{array}{l}\text { FDI, } \mathrm{CO}_{2} \text { Emission, } \\
\text { Renewable Energy } \\
\text { Coefficient }\end{array}$ & $\begin{array}{l}\text { Cointegration } \\
\text { and Granger } \\
\text { Causality Tests }\end{array}$ & FDI has negative effects on sustainable development. \\
\hline $\begin{array}{l}\text { Zamani and Tayebi } \\
(2021)\end{array}$ & $1995-2018$ & $\begin{array}{l}\text { Economic } \\
\text { Cooperation } \\
\text { Organization } \\
\text { Members }\end{array}$ & $\begin{array}{l}\text { FDI, GDP, Labor, Net } \\
\text { Inflows, Trade Volume, } \\
\text { R\&D Expenditures }\end{array}$ & $\begin{array}{l}\text { Panel Data } \\
\text { Analysis }\end{array}$ & There is an impact of spill overs on economic growth. \\
\hline $\begin{array}{l}\text { Guoyan, Khaskheli, } \\
\text { Raza and Şah (2021) }\end{array}$ & $1995-2016$ & $\begin{array}{l}\text { MENA } \\
\text { Countries }\end{array}$ & FDI, $\mathrm{CO}_{2}$ Emission & $\begin{array}{l}\text { Panel } \\
\text { Regression } \\
\text { (PSTR) } \\
\text { Analysis } \\
\end{array}$ & $\begin{array}{l}\text { The link between the FDI and } \mathrm{CO}_{2} \text { emission variables is } \\
\text { not linear. Low levels of FDI increase carbon emissions; } \\
\text { The higher the ratio, the more negative the relationship } \\
\text { becomes. }\end{array}$ \\
\hline $\begin{array}{l}\text { Nepal, Paija, Tyagi } \\
\text { and Harvie (2021) }\end{array}$ & $1978-2016$ & India & $\begin{array}{l}\text { FDI, Energy Use, } \mathrm{CO}_{2} \\
\text { Emissions, GDP and } \\
\text { Trade Openness }\end{array}$ & $\begin{array}{l}\text { ARDL } \\
\text { VECM }\end{array}$ & $\begin{array}{l}1 \% \text { increase in FDI results in } 0.013 \% \text { decrease in energy } \\
\text { use. There is a long-term link between energy, economy, } \\
\text { development and environment. }\end{array}$ \\
\hline
\end{tabular}

Source: It was prepared by us by examining the related studies in the literature. 


\section{Definition of Variables}

In this study, which examines the relationship between sustainable development and foreign direct investment in Turkey, time series of the years 1990-2018 are used. The data sets related to the variables are obtained from the World Bank and Eurostat databases, and econometric analyses are carried out in two separate analyses with the licensed Eviews 10 package program. When the studies in the literature are examined, it is seen that variables such as economic growth, carbon emission rate, energy consumption, trade openness, and R\&D expenditures are used to represent sustainable development. From this point of view, GDP per capita and energy consumption per capita are chosen in this study, due to its decisive role in macroeconomic performance. On the other hand, SDI is chosen as the focus variable, because it contains multiple variables.

The variables considered in the first model are foreign direct investment, per capita gross domestic product and per capita energy consumption, and in the second model, foreign direct investment and SDI.

Table 2. Definition of Variables

\begin{tabular}{|c|c|c|}
\hline Variable & Definition & Explanation \\
\hline \multicolumn{3}{|c|}{ MODEL 1} \\
\hline FDI & Foreign direct investment & World Bank (Million \$) \\
\hline TJ & Energy consumption per person & Eurostat (Kilogram of oil equivalent) \\
\hline GDP & Gross domestic product per capita & World Bank (Million \$) \\
\hline \multicolumn{3}{|c|}{ MODEL 2} \\
\hline FDI & Foreign direct investment & World Bank (\% of GDP) \\
\hline SDI & Sustainable development index & Eurostat \\
\hline
\end{tabular}

Source: It was prepared by us.

In addition, the variation of the variables discussed in the study in the relevant period range in Turkey is shown with the graphs below.

GDP
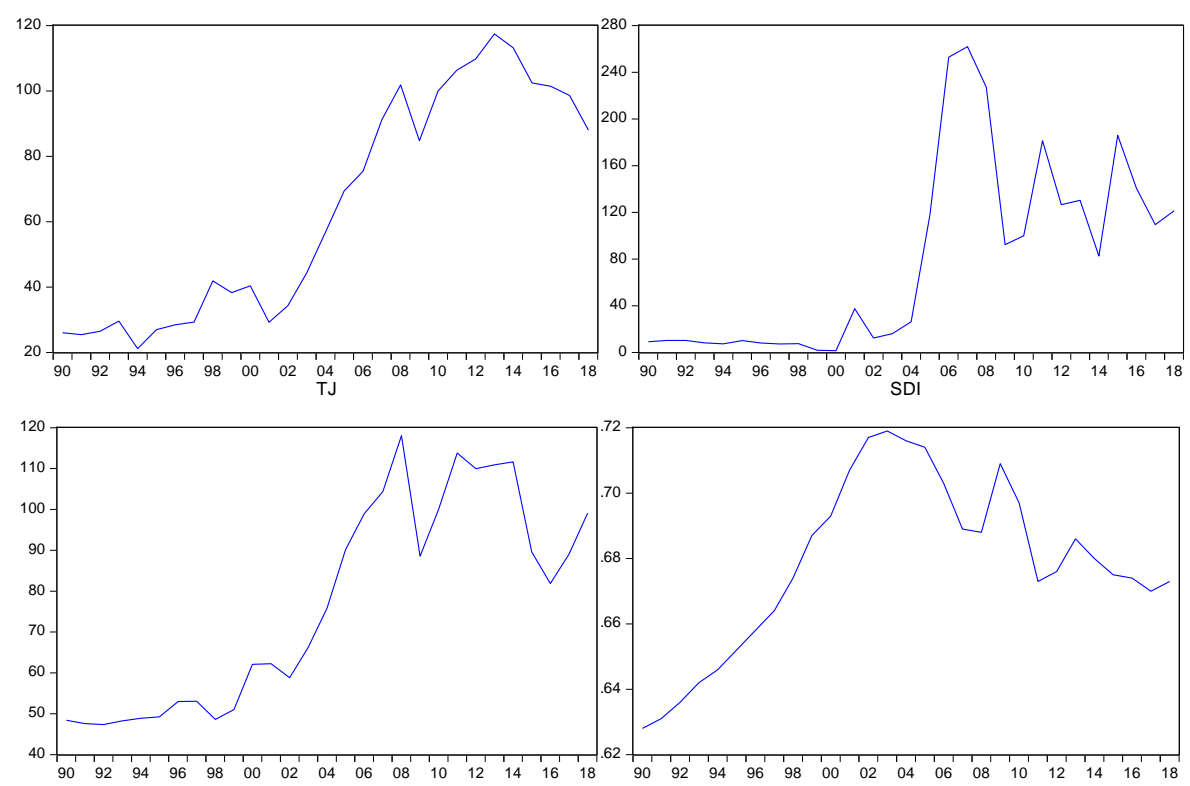

Figure 1. The variation of GDP, FDI, Energy Consumption and SDI 


\section{Empirical Methodology and Result}

In the study, firstly, the lag lengths were determined by using the appropriate lag coefficient Akaike information criterion (AIC). Then the Augmented Dickey-Fuller (ADF) unit root test was used to analyse the stationarity of the variables in order to avoid the spurious regression problem. If the series is stationary, it is analysed to which degree it is stationary. After the series were stationary, Johansen cointegration test was applied and the vector error correction model was created by determining the cointegration relationship between the variables and granger causality was examined. In order to test the suitability of the model, the LM test for the autocorrelation problem, the White test for the heteroscedasticity problem, and the autoregressive unit root test were performed. Finally, the interactions between the variables were investigated using impulseresponse functions and variance decomposition. This study ethics committee approval and/or legal/special permission is not required and research and publication ethics were complied with.

\subsection{Unit Root Test}

In order to obtain meaningful relationships between the variables used in econometric models, the series of the variables should be stationary, in other words, they should not contain unit roots. Extended Dickey-Fuller (ADF) test and Phillips-Perron (PP) test were used in this study to investigate the existence of a unit root. In order to detect significant relationships in series, they must be stationary. In stationary series, the same mean is maintained even if there are long-term fluctuations in the series. It has a time-invariant (finite) variance, and the longer the time lag, the more the correlogram approaches and becomes zero (Kutlar, 2009, p. 318).

The results of the ADF unit root test are obtained using the following equation (Fuller, 1981):

$$
\begin{gathered}
\Delta Y_{t}=\delta Y_{t-1}+\sum_{i=1}^{k} \delta_{i} \Delta_{t-i}+\varepsilon_{t} \\
\Delta Y_{t}=\mu+\delta Y_{t-1}+\sum_{i=1}^{k} \delta_{i} \Delta_{t-i}+\varepsilon_{t} \\
\Delta Y_{t}=\mu+\beta T+\delta Y_{t-1}+\sum_{i=1}^{k} \delta_{i} \Delta_{t-i}+\varepsilon_{t}
\end{gathered}
$$

Here $\Delta$ represents the difference operator, $\mathrm{V}_{\mathrm{t}}$ represents the variable under consideration, and $\varepsilon_{\mathrm{t}}$ represents the error term. The ADF test tests whether the coefficient $\delta$ is statistically equal to zero. This test is performed by comparing the calculated ADF-t statistic with the MacKinnon critical values. The fact that the ADF test statistic is greater than the MacKinnon critical values shows that the time series in question does not contain a unit root.

The results of the PP unit root test are obtained using the following equation:

$$
\widehat{t_{\alpha}}=t_{\alpha}\left(\frac{\gamma_{0}}{f_{0}}\right)^{-1 / 2}-\frac{T\left(f_{0}-\gamma_{0}\right)\left(s_{e}(\hat{\alpha})\right)}{\alpha f^{1 / 2} s}
$$

In equation (4), $s_{e}(\hat{\alpha})$ is the coefficient standard error, $s$ is the standard error of the equation, $\mathrm{T}$ is the number of observations, $\gamma_{0}$ is the consistent estimate of the error variance, and 
$f_{0}$ is the residual spectrum at zero frequency. In the PP test, the hypothesis is that there is a unit root. With the ADF test, the distributions of the statistics are compared with the MacKinnon critical value for the same.

Finding a unit root in the analysis shows that the series are not stationary. This situation causes the spurious regression problem to be encountered in the series and the analysis does not yield correct results. Augmented Dickey-Fuller and PP unit root test were used to determine the stationarity of the series in practice.

Table 3. ADF and Phillips-Peron Unit Root Test Results

\begin{tabular}{|c|c|c|c|c|c|c|c|}
\hline \multirow[t]{2}{*}{$\begin{array}{l}\text { Country } \\
\text { (Period) }\end{array}$} & Variable & \multicolumn{3}{|c|}{ ADF Unit Root Test } & \multicolumn{3}{|c|}{ Phillips-Perron Unit Root Test } \\
\hline & & $\begin{array}{c}\mathrm{t}- \\
\text { Statistics }\end{array}$ & $\begin{array}{c}\text { Critical } \\
\text { Value }\end{array}$ & $\begin{array}{c}\text { Level of } \\
\text { Significance }\end{array}$ & $\begin{array}{c}\text { t- } \\
\text { Statistics }\end{array}$ & $\begin{array}{c}\text { Critical } \\
\text { Value }\end{array}$ & $\begin{array}{c}\text { Level of } \\
\text { Significance }\end{array}$ \\
\hline \multirow{7}{*}{$\begin{array}{l}\text { Turkey } \\
\text { (1990- } \\
2018)\end{array}$} & & & & Model 1 & & & \\
\hline & LFDI & $\begin{array}{c}- \\
6.869479\end{array}$ & $\begin{array}{c}\% 1 \rightarrow- \\
4.374307\end{array}$ & $\begin{array}{c}\text { Stable I(1), } \\
0.01\end{array}$ & $\begin{array}{c}- \\
23.38558\end{array}$ & $\begin{array}{c}\% 1 \rightarrow- \\
4.356068\end{array}$ & $\begin{array}{c}\text { Stable I(1), } \\
0.01\end{array}$ \\
\hline & LGDP & $\begin{array}{c}- \\
5.836068\end{array}$ & $\begin{array}{c}\% 1 \rightarrow- \\
4.374307\end{array}$ & $\begin{array}{c}\text { Stable I(1), } \\
0.01\end{array}$ & $\begin{array}{c}- \\
14.07946\end{array}$ & $\begin{array}{c}\% 1 \rightarrow- \\
4.356068\end{array}$ & $\begin{array}{c}\text { Stable I(1), } \\
0.01\end{array}$ \\
\hline & LTJ & $\begin{array}{c}- \\
4.626896\end{array}$ & $\begin{array}{c}\% 1 \rightarrow- \\
4.394309\end{array}$ & $\begin{array}{c}\text { Stable I(1), } \\
0.01\end{array}$ & $\begin{array}{c}- \\
22.13377\end{array}$ & $\begin{array}{c}\% 1 \rightarrow- \\
4.356068\end{array}$ & $\begin{array}{c}\text { Stable I }(1), \\
0.01\end{array}$ \\
\hline & \multicolumn{7}{|c|}{ Model 2} \\
\hline & LFDI & $\begin{array}{c}- \\
5.678304\end{array}$ & $\begin{array}{c}\% 1 \rightarrow- \\
4.394309\end{array}$ & $\begin{array}{c}\text { Stable I }(1), \\
0.01\end{array}$ & $\begin{array}{c}- \\
5.086767\end{array}$ & $\begin{array}{c}\% 1 \rightarrow- \\
2.653401\end{array}$ & $\begin{array}{c}\text { Stable I }(1) \\
0.01\end{array}$ \\
\hline & SDI & $\begin{array}{c}- \\
8.455620\end{array}$ & $\begin{array}{c}\% 1 \rightarrow- \\
4.374307\end{array}$ & $\begin{array}{c}\text { Stable I(1), } \\
0.01\end{array}$ & $\begin{array}{c}- \\
8.778408\end{array}$ & $\begin{array}{c}\% 1 \rightarrow- \\
3.711457\end{array}$ & $\begin{array}{c}\text { Stable I(1), } \\
0.01\end{array}$ \\
\hline
\end{tabular}

Note: If the ADF test and PP test results of the first-order differenced variables is greater than the table value, the hypothesis that the studied series is stationary $[\mathrm{I}(1)]$ is accepted.

It is a prerequisite for cointegration test that all series are stationary at the same level. The unit root test results of the variables used for Model 1 and Model 2 are given in Table 3. When the first differences of the variables are taken, it is seen that they are stationary at the significance level.

\subsection{Testing for Structural Breaks: Zivot-Andrews}

In studies with time series, there may be structural changes arising from changes such as economic and political crises that took place during the period. Failure to pay attention to the structural changes occurring within the series in unit root tests leads to biased results. In this direction, unit root tests have been developed in which the structural break is detected internally. In this study, Zivot and Andrews (1992) unit root test was used, which is one of the methods that enables the determination of structural break internally.

The results of the Zivot-Andrews unit root test are obtained using the following equation (Zivot and Andrews, 1992, p. 254):

$$
Y_{t}=\mu+\beta t+\delta Y_{t-1}+\theta_{1} D U(\lambda)+\sum_{i=1}^{k} \delta_{i} \Delta Y_{t-i}+\varepsilon_{t} \quad \text { (Model A) }
$$




$$
\begin{array}{cc}
Y_{t}=\mu+\beta t+\delta Y_{t-1}+\theta_{2} D T(\lambda)+\sum_{i=1}^{k} \delta_{i} \Delta Y_{t-i}+\varepsilon_{t} & \text { (Model B) } \\
Y_{t}=\mu+\beta t+\delta Y_{t-1}+\theta_{1} D U(\lambda)+\theta_{2} D T(\lambda)+\sum_{i=1}^{k} \delta_{i} \Delta Y_{t-i}+\varepsilon_{t} & \text { (Model C) }
\end{array}
$$

Model A includes the structural change in the level, Model B in the slope, and Model C in both the slope and the level. $t=1,2, \ldots, T$ stands for time, $T_{B}$ for break time and $\lambda=T_{B} / T$ for relative break point. In the models, DU is the mean and DT is the dummy variable that represents the break in the trend.

$$
D U(\lambda)=\left\{\begin{array}{ll}
1 & t>T_{B} \\
0 & t \leq T_{B}
\end{array} \quad D T(\lambda)= \begin{cases}t-T \lambda & \mathrm{t}>\mathrm{T} \lambda \\
0 & t \leq T_{B}\end{cases}\right.
$$

For the estimation of the breakpoint, $\mathrm{t}=2, \ldots, \mathrm{t}-1) \mathrm{T}-2$ regressions are created using the Least Squares method. The date in the model where the $t$ statistic of the coefficient of the variable $\gamma_{t-1}$ is the smallest is accepted as the structural break point. If the absolute value of the $t$ statistic is less than the Zivot-Andrews critical value after the appropriate break point has been determined, it is considered to be the unit root of the series without structural break.

Table 4. Zivot Andrews Fracture Test Results

\begin{tabular}{llllll}
\hline \multirow{2}{*}{ Variable } & \multicolumn{1}{c}{ Model } & $\begin{array}{c}\text { Break } \\
\text { Point }\end{array}$ & \multirow{2}{*}{ t-statistics } & \multicolumn{2}{c}{ Critical Value } \\
\cline { 3 - 5 } & & \multicolumn{2}{c}{ Model 1 } & \%1 & \%5 \\
\hline \multirow{2}{*}{ LFDI } & Intercept & 2001 & -6.908051 & -5.34 & -4.93 \\
& Trend & 2007 & -6.681107 & -4.80 & -4.42 \\
& Trend and Intercept & 2005 & -6.896745 & -5.57 & -5.08 \\
\hline \multirow{3}{*}{ LGDP } & Intercept & 2011 & -5.258100 & -5.34 & -4.93 \\
& Trend & 2008 & -5.211274 & -4.80 & -4.42 \\
& Trend and Intercept & 2011 & -5.258100 & -5.34 & -4.93 \\
\hline \multirow{3}{*}{ LTJ } & Intercept & 2012 & -7.154622 & -5.34 & -4.93 \\
& Trend & 2007 & -5.994133 & -4.80 & -4.42 \\
& Trend and Intercept & 2012 & -6.943623 & -5.57 & -5.08 \\
\hline \multirow{2}{*}{ LFDI } & & Model 2 & & -4.93 \\
& Intercept & 2009 & -6.278329 & -5.34 & -4.42 \\
& Trend & 2006 & -4.443739 & -4.80 & -5.08 \\
\hline \multirow{2}{*}{ LSDI } & Trend and Intercept & 2009 & -6.194166 & -5.57 & -4.93 \\
& Intercept & 2005 & -3.983275 & -5.34 & -4.42 \\
& Trend & 2012 & -2.579090 & -4.80 & -5.08 \\
\hline
\end{tabular}

Structural break was investigated by the Zivot-Andrews test and is presented in Table 4 . According to the test results presented, the test statistics were greater than the critical value in Model 1 and Model 2 LGDP series is significant at the level of 5\% in the stable (model A) and trend and stable (Model C) models, and at the level of $1 \%$ in the Trend (Model B) model. All other series show significance at the $1 \%$ level. $\mathrm{H}_{0}$ hypothesis was rejected because the series did not contain unit root. 


\subsection{Johansen Cointegration Test}

In econometric models, whether two or more non-stationary series move together in the long run is analysed using the cointegration test. After determining the stationarity of the variables, the appropriate lag lengths for the model should be determined by creating a VAR model for the series. When the relevant literature is examined, it is seen that many criteria are used to determine the lag length. Some of those; Akaike information criterion (AIC), Schwarz information criterion (SC), Hannan-Quinn information criterion (HQ) and Final Error Estimation (FPE) are the most preferred information criteria (Bulut and Özdemir, 2012, p. 218). In this analysis, considering the AIC, the lag length for model 1 was determined as 1 , and the lag length for model 2 was determined as 4 . The results of the Johansen cointegration test with appropriate lag lengths are presented in Table 5.

Table 5. Model 1-2 Johansen Cointegration Test Results

\begin{tabular}{|c|c|c|c|c|c|c|c|c|c|}
\hline \multicolumn{10}{|c|}{$\begin{array}{ll} & \text { MODEL } 1 \\
\end{array}$} \\
\hline \multicolumn{10}{|c|}{$\begin{array}{l}\text { Variables: LFDI, LGDP, LTJ } \\
\text { Lags interval: } 1\end{array}$} \\
\hline \multicolumn{5}{|c|}{ Unrestricted Cointegration Rank Test (Trace) } & \multicolumn{5}{|c|}{$\begin{array}{c}\text { Unrestricted Cointegration Rank Test (Maximum } \\
\text { Eigenvalue) }\end{array}$} \\
\hline $\mathbf{H}_{\mathbf{0}}$ & $\mathbf{H}_{1}$ & $\begin{array}{c}\text { Trace } \\
\text { Statistic } \\
\end{array}$ & $\begin{array}{c}\text { Critical } \\
\text { Value } \% 5\end{array}$ & Prob. & $\mathbf{H}_{\mathbf{0}}$ & $\mathbf{H}_{1}$ & $\begin{array}{c}\text { Trace } \\
\text { Statistic }\end{array}$ & $\begin{array}{c}\text { Critical } \\
\text { Value \%5 }\end{array}$ & Prob. \\
\hline $\mathrm{r}=0$ & $\mathrm{r} \geq 1$ & 46.69608 & 42.91525 & $0.0200^{*}$ & $\mathrm{r}=0$ & $\mathrm{r} \geq 1$ & 25.88127 & 25.82321 & $0.0491 *$ \\
\hline $\mathrm{r} \leq 1$ & $\mathrm{r} \geq 2$ & 20.81481 & 25.87211 & 0.1874 & $\mathrm{r} \leq 1$ & $r \geq 2$ & 14.18603 & 19.38704 & 0.2419 \\
\hline $\mathrm{r} \leq 2$ & $\mathrm{r}=3$ & 6.628785 & 12.51798 & 0.3848 & $\mathrm{r} \leq 2$ & $\mathrm{r}=3$ & 6.628785 & 12.51798 & 0.3848 \\
\hline \multicolumn{10}{|c|}{ MODEL 2} \\
\hline \multicolumn{10}{|c|}{$\begin{array}{l}\text { Variables: FDI, SDI } \\
\text { Lags interval: } 4\end{array}$} \\
\hline \multicolumn{5}{|c|}{ Unrestricted Cointegration Rank Test (Trace) } & \multicolumn{5}{|c|}{$\begin{array}{l}\text { ntegration Rank Test (Maximum } \\
\text { Eigenvalue) }\end{array}$} \\
\hline $\mathbf{H}_{\mathbf{0}}$ & $\mathbf{H}_{1}$ & $\begin{array}{c}\text { Trace } \\
\text { Statistic }\end{array}$ & $\begin{array}{c}\text { Critical } \\
\text { Value } \% 5\end{array}$ & Prob. & $\mathbf{H}_{\mathbf{0}}$ & $\mathbf{H}_{1}$ & $\begin{array}{c}\text { Trace } \\
\text { Statistic }\end{array}$ & $\begin{array}{c}\text { Critical } \\
\text { Value } \% 5\end{array}$ & Prob. \\
\hline$r=0$ & $\mathrm{r} \geq 1$ & 14.65880 & 15.49471 & 0.0666 & $\mathrm{r}=0$ & $r \geq 1$ & 9.100892 & 14.26460 & 0.2778 \\
\hline $\mathrm{r} \leq 1$ & $\mathrm{r}=2$ & 5.557903 & 3.841466 & $0.0184 *$ & $\mathrm{r} \leq 1$ & $\mathrm{r}=2$ & 5.557903 & 3.841466 & $0.0184 *$ \\
\hline
\end{tabular}

Note: *According to the trace and max-eigenvalue tests, there is a cointegrating vector at the $5 \%$ significance level.

In the Johansen cointegration test, the $\mathrm{H}_{0}$ hypothesis states that there is no cointegration relationship between the variables, while the $\mathrm{H}_{1}$ hypothesis states that there is a cointegration relationship between the variables. If the probability values of trace and max-eigenvalue statistics are less than 0.05 significance level, $\mathrm{H}_{0}$ is rejected and $\mathrm{H}_{1}$ hypothesis is accepted. If the probability value is greater than 0.05 , the $\mathrm{H}_{0}$ hypothesis is accepted and the $\mathrm{H}_{1}$ hypothesis is rejected.

When Table 5 was examined, it was observed that the probability value of the trace and maximum eigenvalue statistics is less than 0.05 , and the $\mathrm{H}_{0}$ hypothesis is rejected and the $\mathrm{H}_{1}$ hypothesis is accepted. In other words, there is a cointegration relationship between the variables and they act together in the long run. 


\subsection{Vector Error Correction Model (VECM)}

In models in which a cointegration relationship is detected, it is expected that there will be at least one causality relationship between the variables. In this case, Vector Error Correction Model is applied to determine the causality relationship. Vector Error Correction Model helps to prevent the losses in long-term information caused by the difference operation applied to ensure the stability of the variables (Erdil Şahin, 2019, p. 70).

Table 6. Granger Causality Test Based on VECM Result

\begin{tabular}{|c|c|c|c|c|}
\hline \multicolumn{5}{|c|}{ MODEL 1} \\
\hline \multicolumn{5}{|c|}{ Dependent variable: LGDP } \\
\hline Excluded & Chi-sq & $\mathrm{df}$ & Prob. & Direction of causality \\
\hline LFDI & 5.855721 & 1 & $0.0155^{*}$ & $\mathrm{LFDI} \rightarrow \mathrm{LGDP}$ \\
\hline LTJ & 5.176867 & 1 & $0.0229 *$ & $\mathrm{LTJ} \rightarrow \mathrm{LGDP}$ \\
\hline \multicolumn{5}{|c|}{ Dependent variable: $\mathbf{L T J}$} \\
\hline Excluded & Chi-sq & df & Prob. & Direction of causality \\
\hline LFDI & 4.317279 & 1 & $0.0377 *$ & $\mathrm{LFDI} \rightarrow \mathrm{LTJ}$ \\
\hline LGDP & 3.978020 & 1 & $0.0461 *$ & $\mathrm{LGDP} \rightarrow \mathrm{LTJ}$ \\
\hline \multicolumn{5}{|c|}{ Dependent variable: LFDI } \\
\hline Excluded & Chi-sq & df & Prob. & Direction of causality \\
\hline LGDP & 0.966785 & 1 & 0.3255 & \multirow{2}{*}{ No relationship } \\
\hline LTJ & 0.691990 & 1 & 0.4055 & \\
\hline \multicolumn{5}{|c|}{ MODEL 2} \\
\hline \multicolumn{5}{|c|}{ Dependent variable: FDI, SDI } \\
\hline Excluded & Chi-sq & df & Prob. & Direction of causality \\
\hline FDI & 9.760642 & 4 & $0.0447 *$ & \multirow{2}{*}{$\mathrm{FDI} \rightarrow \mathrm{SDI}$} \\
\hline SDI & 3.102370 & 4 & 0.5408 & \\
\hline
\end{tabular}

Note: If the probability value is 0.05 and less than 0.01 , the relevant hypothesis is rejected at $5 \%$ and $1 \%$ significance levels.

According to the results of the Granger causality test based on the vector error correction model, when model 1 is examined, it has been determined that there is a one-way relationship from foreign direct investment to gross domestic product per capita and energy consumption per capita. It is also observed that there is bidirectional causality between the per capita gross domestic product variable and per capita energy consumption variables. In Model 2, on the other hand, a one-way relationship from foreign direct investment to SDI has been determined.

\subsection{Testing the Suitability of the VAR Model}

The VAR model is a work of Simms proposed in 1980. It is a multivariate time series model, which is an extension of the univariate autoregressive process. It describes the dynamic behavior of economic time series and shows the interdependence between the variables. It also predicts the potential paths that a selected variable will follow in the future (Erden and Turan Koyuncu, 2014, p. 17-18). An important point in establishing the VAR model is to determine the appropriate lag length. The lag lengths according to the LogL, FPE, AIC, SC and HQ criteria used to find the lag length are given in Table 7. 
Table 7. Determination of VAR Lag Length

\begin{tabular}{lccccc}
\hline \multicolumn{7}{c}{ MODEL 1 } \\
\hline Lag & LogL & FPE & AIC & SC & HQ \\
\hline 1 & -108.6340 & $4.704966^{*}$ & $10.05283^{*}$ & 10.64186 & 10.20910 \\
2 & -105.2504 & 7.842494 & 10.52087 & 11.55166 & 10.79434 \\
3 & -92.02528 & 6.153687 & 10.16877 & 11.64134 & 10.55945 \\
4 & -87.38638 & 11.10766 & 10.53220 & 12.44654 & 11.04007 \\
\hline Lag & LogL & FPE & AIC & SC & HQ \\
\hline 1 & -49.76952 & 0.302950 & 4.480793 & $4.677136^{*}$ & 4.532883 \\
2 & -47.75075 & 0.359306 & 4.645896 & 5.038580 & 4.750075 \\
3 & -44.11317 & 0.376060 & 4.676097 & 5.265124 & 4.832366 \\
4 & -35.61018 & $0.266616^{*}$ & $4.300848^{*}$ & 5.086217 & $4.509207^{*}$ \\
\hline
\end{tabular}

Note: *Appropriate lag length.

Since the number of observations was less than 60 , in order to get more accurate results, FPE and AIC information criteria were preferred for the model, and the appropriate lag length was determined as 1 for model 1 and 4 for model 2. At the same time, in order to see if there is a structural problem in the VAR model, it was tested by applying the LM test for autocorrelation and the White test for heteroscedasticity. The results are presented in Table 8.

Table 8. Autocorrelation and Variance Testing

\begin{tabular}{|c|c|c|c|c|}
\hline \multicolumn{5}{|c|}{ MODEL 1} \\
\hline \multicolumn{3}{|c|}{ Autocorrelation } & \multicolumn{2}{|c|}{ None Constant Variance } \\
\hline Lag & LRE statistics & Prob. & Chi-sq & Prob. \\
\hline 1 & 3.313277 & 0.9509 & \multirow{2}{*}{43.74620} & \multirow{2}{*}{0.1757} \\
\hline 2 & 3.818673 & 0.9234 & & \\
\hline \multicolumn{5}{|c|}{ MODEL 2} \\
\hline \multicolumn{3}{|c|}{ Autocorrelation } & \multicolumn{2}{|c|}{ None Constant Variance } \\
\hline Lag & LRE statistics & Prob. & Chi-sq & Prob. \\
\hline 1 & 5.911417 & 0.2069 & \multirow{5}{*}{65.20650} & \multirow{5}{*}{0.1412} \\
\hline 2 & 13.95491 & 0.3231 & & \\
\hline 3 & 20.06681 & 0.1773 & & \\
\hline 4 & 18.84894 & 0.1915 & & \\
\hline 5 & 31.55056 & 0.2529 & & \\
\hline
\end{tabular}

In the autocorrelation test performed to determine the relationship between the error terms in the VAR model, no autocorrelation problems were encountered at 2 lag levels for model 1 and at 5 lag levels for model 2. In addition, the White test results for the heteroscedasticity problem show that there is no problem of varying variance in the Chi-square value, that is, the variance of the error terms is the same in all observations. Finally, the stationarity of the model was tested with the autoregressive unit root test of the model. All the inverse roots of the AR characteristic polynomial were found in the circle and it was determined that the VAR model satisfies the stability condition.

\subsection{Action-Response Functions}

The impulse-response functions reflect the effect of a standard deviation shock in one of the random error terms on the present and future values of the endogenous variables. In VAR 
analysis, action-response functions have a great role in determining the dynamic interaction between the variables examined and detecting symmetrical relationships. Variance decomposition distinguishes the change in one of the endogenous variables as separate shocks affecting all the endogenous variables. In this sense, variance decomposition gives information about the dynamic structure of the system. The purpose of variance decomposition is to reveal the effect of each random shock on the error variance of the forecast for future periods. While the most effective variable on a macroeconomic size is determined by variance decomposition, whether this variable can be used as a policy tool is determined by the impact-response functions (Sar1, 2008, p. 4).

In this section, graphs showing the reactions of other variables against a standard error shock occurring in the variables used for model 1 and model 2 are given. The solid lines (blue) in the graphs show the response of other variables over time to a standard error shock occurring in the error terms of the model.

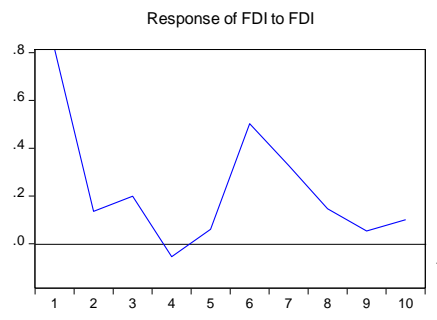

Response of SDI to SDI

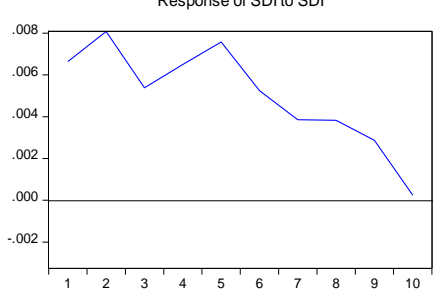

Response of LFDI to LGDP

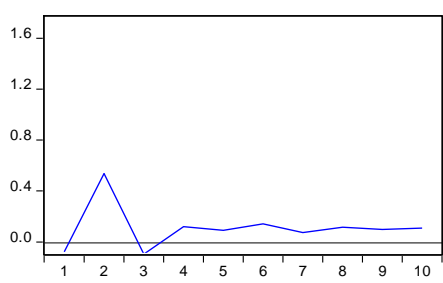

Response of LFDI to LTJ

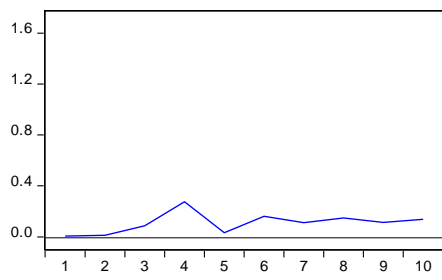

Response of LFDI to LFDI

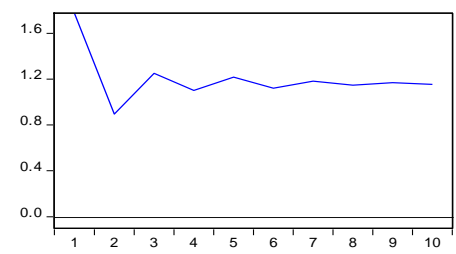

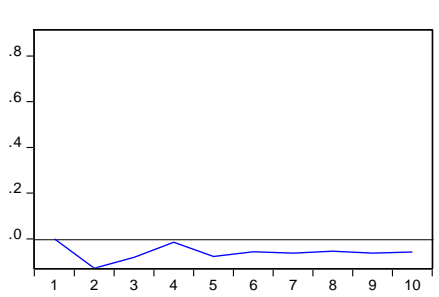

Response of SDI to FDI

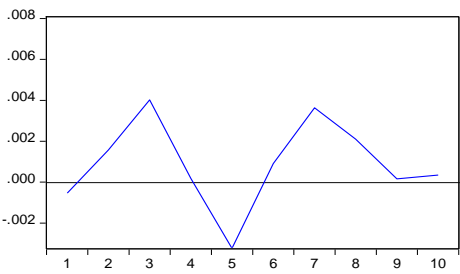

Kesponse or LGiUP to LGiUr

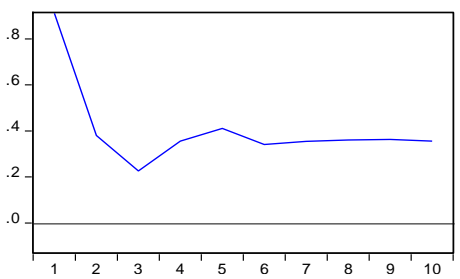

Response of LGDP to LTJ

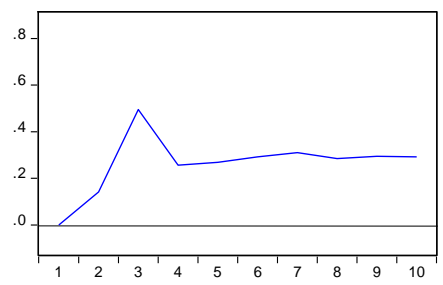

Response of LGDP to LFDI
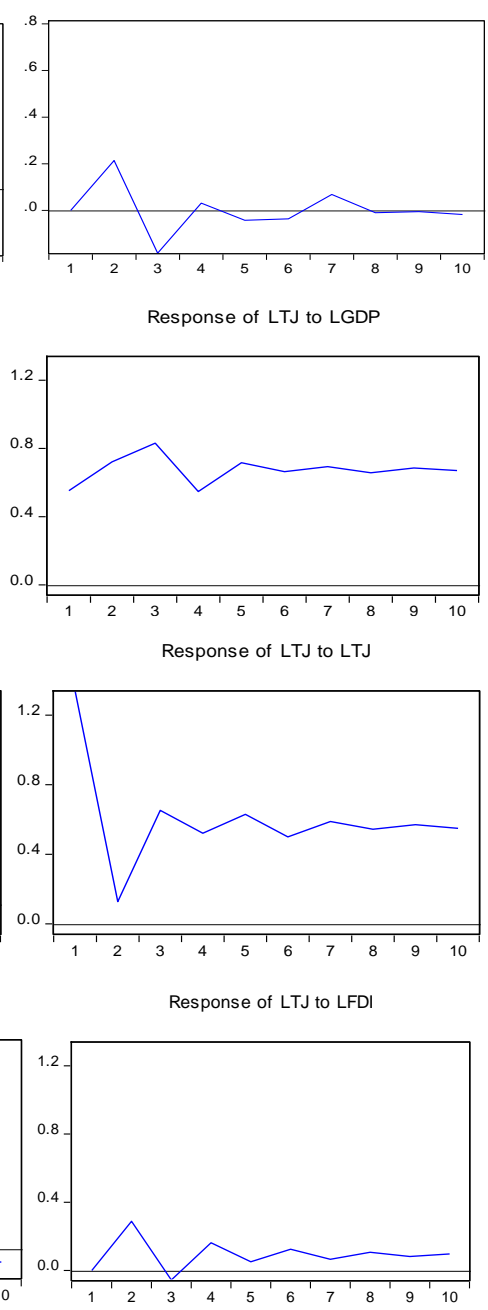

Response of LTJ to LGDP

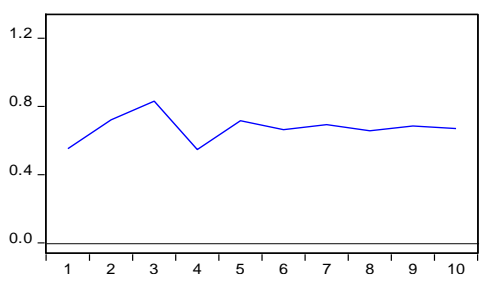

Response of LTJ to LTJ

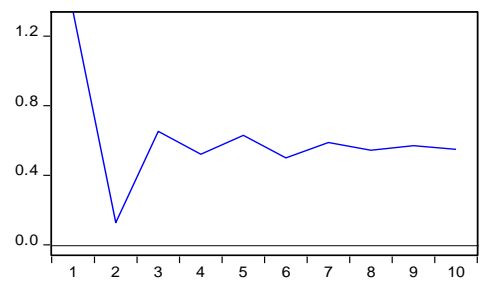

Response of LTJ to LFDI

Figure 2. Model 1 and Model 2 Impulse Response Functions 


\subsection{Variance Decomposition}

Variance decomposition shows how much of the changes in dependent variables are caused by their own shocks and how much is caused by the shocks of other variables (Barişik and Kesikoğlu, 2006, p. 77). In Table 9 and Table 10, variance decomposition of the variables used in the models is shown for 10 periods in order to examine the relationship between sustainable development and foreign direct investment.

Table 9. Variance Decomposition Results of Model 1 Variables (\%)

\begin{tabular}{|c|c|c|c|}
\hline \multicolumn{4}{|c|}{ MODEL 1} \\
\hline \multirow[t]{2}{*}{ Period } & \multicolumn{3}{|c|}{ Variance Decomposition of LFDI } \\
\hline & LFDI & LGDP & LTJ \\
\hline 1 & 100.0000 & 0.000000 & 0.000000 \\
\hline 2 & 69.72845 & 25.78279 & 4.488756 \\
\hline 3 & 70.23230 & 24.37610 & 5.391600 \\
\hline 4 & 73.16929 & 22.07818 & 4.752534 \\
\hline 5 & 72.11665 & 22.87412 & 5.009232 \\
\hline 6 & 70.31176 & 24.32481 & 5.363433 \\
\hline 7 & 71.11620 & 23.61268 & 5.271120 \\
\hline 8 & 71.25807 & 23.52268 & 5.219256 \\
\hline 9 & 70.79346 & 23.87560 & 5.330941 \\
\hline 10 & 70.75103 & 23.89723 & 5.351740 \\
\hline \multirow[t]{2}{*}{ Period } & \multicolumn{3}{|c|}{ Variance Decomposition of LGDP } \\
\hline & LGDP & LFDI & LTJ \\
\hline 1 & 91.14176 & 7.858240 & 0.000000 \\
\hline 2 & 80.64365 & 17.23297 & 2.123384 \\
\hline 3 & 67.39922 & 28.15573 & 4.445052 \\
\hline 4 & 66.74641 & 25.43835 & 7.815246 \\
\hline 5 & 67.26769 & 29.31085 & 8.421453 \\
\hline 6 & 63.75865 & 32.80037 & 8.440983 \\
\hline 7 & 62.52729 & 34.03401 & 9.438703 \\
\hline 8 & 62.21758 & 34.53274 & 9.249674 \\
\hline 9 & 61.38694 & 35.42360 & 9.189463 \\
\hline 10 & 60.46343 & 36.37418 & 9.162399 \\
\hline \multirow[t]{2}{*}{ Period } & \multicolumn{3}{|c|}{ Variance Decomposition of LTJ } \\
\hline & LTJ & LFDI & LGDP \\
\hline 1 & 81.52204 & 5.275329 & 13.20263 \\
\hline 2 & 68.91288 & 4.163842 & 26.92328 \\
\hline 3 & 60.48549 & 7.249025 & 32.26549 \\
\hline 4 & 62.18867 & 6.281606 & 31.52972 \\
\hline 5 & 60.55229 & 6.630937 & 32.81678 \\
\hline 6 & 58.99214 & 6.155270 & 34.85259 \\
\hline 7 & 58.82383 & 6.006016 & 35.17016 \\
\hline 8 & 58.79005 & 5.688621 & 35.52133 \\
\hline 9 & 58.19391 & 5.619391 & 36.18670 \\
\hline 10 & 57.92248 & 5.455214 & 36.62230 \\
\hline
\end{tabular}

While the variances of the variables are mostly explained by themselves in the first periods, this ratio decreases towards the 10th period. While the variance of the variable of foreign direct investment is explained by itself according to the average of 10 periods, $21.43 \%$ of the variance of the variance of foreign direct investment is explained by the per capita gross domestic product and $5.13 \%$ by the energy consumption per capita. While the LGDP variable was explained by itself by $91.14 \%$ in the first period, this rate decreased by $68 \%$ compared to the average of 10 
periods, and $28.11 \%$ of the change in its variance was caused by the LFDI and $7 \%$ by the LTJ variable. In the LTJ variable, $81.52 \%$ originates from itself in the first period, $5.85 \%$ is caused by the LFDI variable compared to the average of 10 periods, and $31.50 \%$ is caused by the LGDP variable.

Table 10. Variance Decomposition Results of Model 2 Variables (\%)

\begin{tabular}{lcc}
\hline & \multicolumn{2}{c}{ MODEL 2 } \\
\hline \multirow{2}{*}{ Period } & FDI & SDI \\
\hline 1 & 100.0000 & 0.000000 \\
2 & 93.68670 & 6.313300 \\
3 & 90.04189 & 9.958110 \\
4 & 89.96824 & 10.03176 \\
5 & 89.81853 & 10.18147 \\
6 & 92.13630 & 7.863702 \\
7 & 92.48989 & 7.510115 \\
8 & 92.61794 & 7.382059 \\
9 & 92.63345 & 7.366548 \\
10 & 92.67339 & 7.326613 \\
\hline \multirow{2}{*}{ Period } & Variance Decomposition of SDI \\
\hline 1 & SDI & FDI \\
2 & 99.35164 & 0.648359 \\
3 & 97.53864 & 2.461363 \\
4 & 87.97667 & 12.02333 \\
5 & 90.51056 & 9.489443 \\
6 & 88.99797 & 11.00203 \\
7 & 89.77505 & 10.22495 \\
8 & 86.58058 & 13.41942 \\
9 & 86.03519 & 13.96481 \\
10 & 86.35541 & 13.64459 \\
\hline & 86.32882 & 13.67118 \\
\hline
\end{tabular}

The variance decomposition results for Model 2 variables are presented in Table 10. It is seen that the variables are mostly explained by themselves in the first periods, as in model 1. Looking at the average of 10 periods, it was observed that $92.60 \%$ of the FDI variable was explained by itself, while $7.39 \%$ was explained by the SDI variable. While the SDI variable was explained by him at the rate of $99.35 \%$ in the first period, it is seen that $89.94 \%$ of it and $10.05 \%$ of it was caused by the FDI variable in the 10-term average.

\section{Conclusion}

The 17 sustainable development goals created by the United Nations on basic elements such as poverty, climate change, economic inequality, innovation, sustainable consumption, peace and justice also have social, economic and environmental dimensions. The adoption of 17 sustainable development goals also includes the need for investments for international communities. In terms of sustainable development goals, private sector and foreign direct investments are of great importance, besides public investments (Aust et al. 2020). Furthermore, the development priorities of developing countries include sustainable economic growth, increased investment, increasing export power in world markets, creating more and better employment opportunities, strengthening technological development and protecting the 
environment for future generations. The liberalization and globalization trends in the world economy put pressure on developing countries to develop their own resources and capacities to achieve these goals.

Especially underdeveloped and developing countries may experience difficulties in reaching these targets due to their low socioeconomic development. For these countries, foreign direct investment can create an opportunity to achieve sustainable development goals (Gallagher, 2005). Since the early 1990s, foreign direct investment has been recognized as an 'engine of development' for developing countries, especially by organizations such as UNCTAD, and this acceptance has been confirmed in practice. Liberalization policies, liberalization in international capital movements, privatization practices, cross-border mergers and acquisitions, favourable international environment, developments in communication and transportation technologies, securing contracts, reducing nationalization risks increase foreign direct investments towards developing countries. Regional integrations are another factor supporting the increase in foreign investment flows. Thus, the acceleration of foreign direct investments has increased the effectiveness of countries' economies and improves conditions for sustainable development.

According to findings of the study, examining the relationship between foreign direct investment and sustainable development by using time series of Turkey's 1990-2018 periods, there is a co-integration relationship between the variables and they act together in the long run. In addition, the following conclusions are reached in the study that there is a one-way relationship from foreign direct investment to per capita gross domestic product and per capita energy consumption and there is bidirectional causality between per capita gross domestic product and per capita energy consumption the existence of a one-way relationship from foreign direct investment to the SDI. In this context, the findings support the idea that FDI increase creates significant direct economic effects such as increased income to the host country, higher employment and growth rate from an economic development perspective. In this respect, with the results obtained from the study, Turkey's legislative improvements to attract more FDI and taking measures to ensure macroeconomic stability will have favourable results for its sustainable development.

\section{Researcher's Contribution Rate Statement}

The authors declare that they have contributed equally to the article.

\section{Researcher's Conflict of Interest Statement}

There is no potential conflicts of interest in this study. 


\section{Rerefences}

Abdouli, M. and Hammoni S. (2017). Investigating the causality links between environmental quality, foreign direct investment and economic growth in MENA countries. International Business Review, 26, 264-278. https://doi.org/10.1016/j.ibusrev.2016.07.004

Adejumo, A. V. (2019). Foreign direct investment, export performance and sustainable development in Nigeria. Journal of Sustainable Development, 12(2), 110-122. doi:10.5539/jsd.v12n2p110

Antanavičienè, J. (2014). Foreign direct investment: Driving factors and outcomes for secure and sustainable development. Journal of Security and Sustainability Issues, 3(3), 55-67. doi:10.9770/jssi.2014.3.3(5)

Aust, V., Morais, A. I. and Pinto I. (2020). How does foreign direct investment contribute to sustainable development goals? Evidence from African Countries. Journal of Cleaner Production, 245, 1-10. https://doi.org/10.1016/j.jclepro.2019.118823

Ayamba, E. C., Haibo, C., Abdul-Rahaman, A. R., Serwaa, O. E. and Osei-Agyemang, A. (2020). The impact of foreign direct investment on sustainable development in China. Environmental Science and Pollution Research, 27(20), 25625-25637. https://doi.org/10.1007/s11356-020-08837-7

Barişik, S. and Kesikoğlu, F. (2006). Türkiye'de bütçe açiklarinin temel makroekonomik değişkenler üzerine etkisi (1987-2003 VAR, etki-tepki analizi, varyans ayrıştırması). Ankara Üniversitesi SBF Dergisi, 61(4), 59-82. Retrieved from https://dergipark.org.tr/en/pub/ausbf

Bulut, S. and Özdemir, A. (2012). İstanbul Menkul Kıymetler Borsası ve "Dow Jones Industrial" araştırma ilişkisi: Eşbütünleşme analizi. Yönetim ve Ekonomi Dergisi, 19(1), 211-224. Retrieved from https://dergipark.org.tr/tr/pub/yonveek

Cho, H. C. and Ramirez, M. D. (2016). Foreign direct investment and income inequality in Southeast Asia: A panel unit root and panel cointegration analysis, 1990-2013. Atlantic Economic Journal, 44, 411424. doi:10.1007/s11293-016-9521-7

Chudnovsky, D. and Lopez, A. (2008). Foreign investment and sustainable development in Argenita. Retrieved from http://citeseerx.ist.psu.edu/viewdoc/summary?doi=10.1.1.367.818

Davidson, L. and Sahli, M. (2015). Foreign direct investment in tourism, poverty alleviation, and sustainable development: A review of the Gambian hotel sector. Journal of Sustainable Tourism, 23(2), 167-187. Retrieved from https://sdgs.un.org/

Erden, C. and Turan Koyuncu, F. (2014). Kalkınma ve çevresel sağlık riskleri: Türkiye için ekonometrik bir analiz. Aksaray Üniversitesi İktisadi ve Iddari Bilimler Fakültesi Dergisi, 6(2), 9-23. Retrieved from https://iibfdergi.aksaray.edu.tr/

Erdil Şahin, B. (2019). Türkiye'de enflasyon ve işsizlik arasındaki ilişkinin vektör hata düzeltme modeli ile analizi. Mali Çözüm Dergisi, 29(152), 63-75. Retrieved from https://archive.ismmmo.org.tr/

Feridun, M. and Sissoko, Y. (2011). Impact of FDI on economic development: A causality analysis for Singapore, 1976 - 2002. International Journal of Economic Sciences and Applied Research, 4(1), 7-11. Retrieved from http://ssrn.com/

Fuller, D. (1981). Likelihood ratio statistics for autoregressive time series with a unit root. Econometrica, 49(4), 1057-1072. doi:10.2307/1912517

Gallagher, K. P. (2005). FDI as a sustainable development strategy: Evidence from Mexican manufacturing. UC Berkeley: Center for Latin American Studies.

Georgantopoulos, A. G. and Tsamis, A. (2011). The macroeconomic effects of budget deficits in Greece: A VAR-VECM approach. International Research Journal of Finance and Economics, 79, 100-112. Retrieved from https://ssrn.com/

Guoyan, S., Khaskheli, A., Raza, S. A. and Shah, N. (2021). Analyzing the association between the foreign direct investment and carbon emissions in MENA countries: A pathway to sustainable development. Environment, Development and Sustainability, 1-18. doi:10.1007/s10668-021-01613-8 
Kardos, M. (2014). The relevance of foreign direct investment for sustainable development. Empirical evidence from European Union. Procedia Economics and Finance, 15, 1349-1354. https://doi.org/10.1016/S2212-5671(14)00598-X

Karimov, M. (2020). An empirical analysis of the relationship among foreign direct investment, gross domestic product, $\mathrm{CO} 2$ emissions, renewable energy contribution in the context of the Environmental Kuznets Curve and pollution haven hypothesis regarding Turkey. European Center for Science Education and Research, 94-108. doi:10.26417/ejef.v4i1.p110-123

Kivyiro, P. and Arminen, H. (2014). Carbon dioxide emissions, energy consumption, economic growth, and foreign direct investment: Causality analysis for Sub-Saharan Africa. The Energy Journal, 74, 595-606. https://doi.org/10.1016/j.energy.2014.07.025

Kutlar, A. (2009). Uygulamalı ekonometri. Ankara: Nobel Yayın Dağıtım.

Mukhtarov, S., Aliyev, S., Mikayilov, J. I., Ismayilov, A. and Rzayev, A. (2021). The FDI-CO2 nexus from the sustainable development perspective: The case of Azerbaijan. International Journal of Sustainable Development \& World Ecology, 28(3), 246-254. https://doi.org/10.1080/13504509.2020.1804479

Nepal, R., Paija, N., Tyagi, B. and Harvie, C. (2021). Energy security, economic growth and environmental sustainability in India: Does FDI and trade openness play a role? Journal of Environmental Management, 281, 111886. https://doi.org/10.1016/j.jenvman.2020.111886

Odugbesan, J. A., Ike, G., Olowu, G. and Adeleye, B. N. (2020). Investigating the causality between financial inclusion, financial development and sustainable development in Sub-Saharan Africa economies: The mediating role of foreign direct investment. Journal of Public Affairs, e2569. https://doi.org/10.1002/pa.2569

Omri, A., Nguyen, D. K. and Roult, C. (2014). Causal interactions between CO2 emissions, FDI, and economic growth: Evidence from dynamic simultaneous-equation models. Economic Modelling, 42, 18-40. https://doi.org/10.1016/j.econmod.2014.07.026

Pao, H. T. and Tsai, C. M. (2011). Multivariate Granger causality between CO2 Emissions, energy consumption, FDI (foreign direct investment) and GDP (gross domestic product): Evidence from a panel of BRIC (Brazil, Russian Federation, India, and China) countries. The Energy Journal, 36, 685-693. https://doi.org/10.1016/j.energy.2010.09.041

Park, S. D. (2018). The nexus of FDI, R\&D, and human capital on Chinese sustainable development: Evidence from a two-step approach. Multidisciplinary Digital Publishing Institute, 10, 1-23. doi:10.3390/su10062063

Pirtea, M. and Milos, L. (2009). Foreign direct investment-a lead driver for sustainable development in Romania? Annals-Economy Series, 3, 265-272. Retrieved from https://www.utgjiu.ro/

Rana, R. and Sharma, M. (2020). Dynamic causality among FDI, Economic Growth and CO2 emissions in India with open markets and technology gap. International Journal of Asian Business and Information Management, 11(3), 15-31. doi:10.4018/IJABIM.2020070102

Ren, S., Yuan, B., Ma, X. and Chen, X. (2014). International trade, FDI (foreign direct investment) and embodied CO2 emissions: A case study of Chinas industrial sectors. China Economic Review, 28, 123-134. https://doi.org/10.1016/j.chieco.2014.01.003

Ridzuan, A. R., Ismail, N. A. and Hamat, A. F. C. (2017). Does foreign direct investment successfully lead to sustainable development in Singapore? The Economies Journal, 5(29), 2-20. https://doi.org/10.3390/economies5030029

Ridzuan, A. R., Ismail, N. A. and Hamat, A. F. C. (2018). Foreign direct investment and trade openness: Do they lead to sustainable development in Malaysia? Journal of Sustainability Science and Management, 4, 81-100. Retrieved from https://jssm.umt.edu.my/

Sarı, A. (2008). Parasalcı görüşe göre Türkiye'de ödemeler bilançosu dengesinin sağlanmasında otomatik denkleşme mekanizmalarının etkinliği. C. Ü. Íktisadi ve İdari Bilimler Dergisi, 9(2), 1-12. Retrieved from https://library.dogus.edu.tr/mvt/ 
Šimelytė, A. and Antanavičienė, J. G. (2013). Foreign direct investment policy as an instrument for sustainable economic growth: A case of Ireland. Journal of Security and Sustainability Issues, 2(4), 25-34. http://dx.doi.org/10.9770/jssi.2013.2.4(3)

Simionescu, M. (2016). Foreign direct investment and sustainable development. A regional approach for Romania (Macroeconomic Modelling Seminar Working Papers No. 162702). Retrieved from https://ipe.ro/repec/workingpapers/cs27_2.pdf

United Nations Conference on Trade and Development. (2014). World investment report 2014 - Investing in the SDGs: An action plan. Retrieved from https://unctad.org/system/files/officialdocument/wir2014_en.pdf

United Nations. (2015). Transforming our world: The 2030 agenda for sustainable development. Retrieved from https://sustainabledevelopment.un.org/post2015/transformingourworld/publication

Voica, M. C., Panait, M. and Haralambie, G. A. (2015). The impact of foreign direct investment on sustainable development. Economic Insights - Trends and Challenges, 3, 89-103. Retrieved from https://upg-bulletin-se.ro/

Zamani, Z. and Tayebi, S. K. (2021). The causal links between FDI and economic development: Evidence from Greece. European Journal of Social Sciences, 27(1), 12-20. Retrieved from http://www.europeanjournalofsocialsciences.com

Zivot, E. and Andrews D. (1992). Further evidence on the great grash, the oil-price shock, and the unit-root hypothesis. Journal of Business and Economic Statistics, 10(3), 251-270. Retrieved from http://www.jstor.org/ 